\title{
Christian theological understanding of the handling of infertility and its relevance in the Indonesian context
}

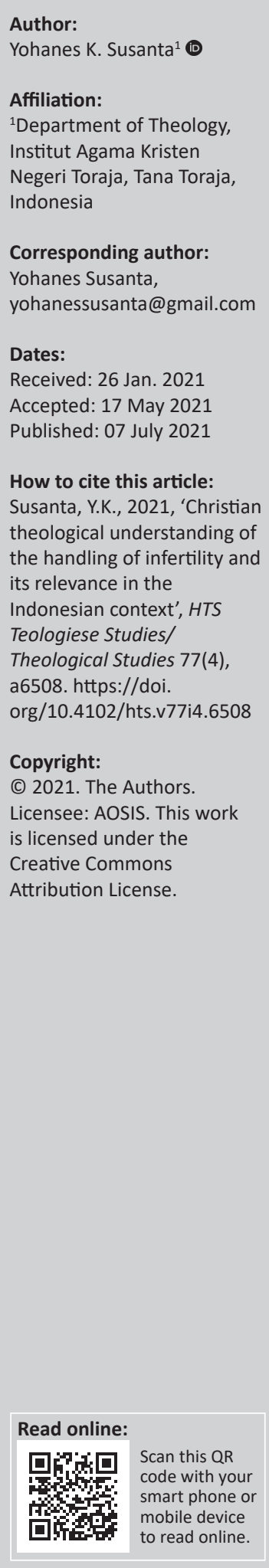

Infertility is one of the key themes in the Old Testament narrative. This infertility was experienced by the Israelite matriarchs Sarai, Rebekah and Rachel as well as several other women. This article argues that the concept infertility has given rise to injustice and discrimination, especially against women. For this reason, a constructive and a contextual dialogue between the biblical context and the context of the present is required to offer a new understanding and a liberating spirit to women and men. It is crucial because there is a traditional assumption that infertility is a disgrace and misfortune for a family. The inability to have children can create problems in the home, such as divorce or polygamy for the sake of having children. Infertility constitutes a severe problem for couples in a culture that emphasises the importance of producing descendants.

Contribution: This article offers a theological contribution from the Old Testament as a critique of the culture in terms of how infertile women are treated, that is, infertility as God's grace. Also, this article offers a Christian theological understanding of the handling of infertility in an Indonesian context. It aims to redefine infertility and bring each couple to the realisation that the plight of infertility or having no children should no longer be seen as a burden for a couple but rather as part of God's grace for their lives.

Keywords: infertile women; descendants; ancient Israel; God's grace; Indonesia.

\section{Introduction}

For most ethnic groups in Indonesia, children are the dream and hope of every family. In Javanese culture (one of the tribes in Indonesia), there is a phrase 'many children, many sustenances'. This expression's meaning is: a family with many children hopes that the family will be fulfilled with sustenance and prosperity. Therefore, the opposite condition - sterility becomes a scourge for every family (Susanta 2017). If offspring is seen as hope, infertility becomes a severe problem for every family. Unfortunately, when couples fail to have children it is often blamed on the woman. In such circumstances, we can expect that a wife will feel ashamed from a social point of view, whereas from a psychological point of view, she will likely be very depressed. From a religious or spiritual point of view, a wife may feel guilty because she thinks that her inability to produce offspring is because of sins or mistakes she has committed in the past (Sanjaya 2014:21).

A child's presence is hope for almost all families in Indonesia. For example, for the Toraja tribe, the descent is essential for two basic things. Firstly, the tongkonan [traditional Toraja house] is a sign of fellowship and brotherhood amongst grandmothers' descendants. Therefore, if there were no descendants, no one would build the tongkonan. Secondly, there is a death feast $\left(\right.$ rambusolo $\left.^{\prime}\right)$. If there is no offspring, no one will perform the funeral ceremony (Ihromi 1981).

The importance of having children is also found in Balinese life. Families without children are considered as disadvantaged families. The term that appears to describe this condition is Nang Pocol and Men Pocol or Nang Bekung and Men Bekung (pocol means loss whilst bekung means infertile. Nang means father whilst Men means mother) (Astiti 1999). In Balinese families, having many children is important because it is considered a way to pay parents' debts. It is confirmed by the view that a person only reaches their life goals after having grandchildren, which is evident in the expression that reads, 'I Cucu nyupat I Kaki' [his grandson saved his grandfather] (Astiti 1999:228). 
Living in the midst of Indonesian society that tends to demand and measure one of the values of family success is that children's presence is indeed a challenge, especially for every family that has not had children even though they have been married for a long time. Some often see the absence of children in the family as abnormal. In this context, the church has a major role to play in correcting misconceptions about heredity and sterility. The church needs to provide the correct understanding so that couples who do not have children need not feel ashamed in their community and think of instant solutions such as divorce or remarriage. By providing the correct understanding, the congregation, especially childless married couples, need not feel ashamed, let alone think that infertility is a punishment from God.

When dealing with various life problems, for Christians the Bible as a book of faith is regarded as having a bearing in today's life situations. Therefore, Christians do latch on biblical stories, which also relate or resonate with their current circumstances. As such, biblical stories of infertility or barrenness play an essential role for the good or the bad depending on how they are interpreted. Therefore, the next part of this article will highlight the Old Testament stories of Israel's matriarchs infertility.

\section{The stories of the infertility of the Israelite matriarchs: Happy ending stories}

Interestingly, the sterility of a wife is often the starting point of a narrative (Gn 11:30; 25:21; 29:31; Jdg 13:2; 1 Sm 1) (Albertz \& Schmitt 2012:270). There are several infertile women in the Bible such as Sarah, Rebekah, Rachel, Hannah, Samson's Mother, Sunamite women, Michal and others. The article will focus more on the Israelites matriarchs' sterility, namely Sarai, Rebekah and Rachel.

\section{Sarai}

Information about Sarai first appeared in Genesis 11:30 where it is clear that Sarai, Abram's wife was infertile and had no children. It is repeated at the beginning of the narrative in Genesis 16:1. Sarai said that her inability to give birth was because of God. This condition became one reason for Sarai to find a surrogate mother through the slave girl, Hagar. The status of a child born from the womb of a slave girl is the child of the mistress. However, after Hagar became pregnant, she looked down on her mistress, which created family problems. The story that follows shows that God wanted offspring from Sarai's womb, not Hagar (Gn 17:15-22). Finally, in Genesis 21 it says:

The Lord took care of Sarah, as He said, and the Lord did to Sarah as He promised. So Sarah became pregnant, and she gave birth to a son to Abraham in his old age, at the appointed time, according to the word of God to him. (vv. 1-2)

\section{Rebekah}

Abraham did not want Isaac to marry a Canaanite woman. He wanted a wife for Isaac, who was from his family. It is not surprising because Isaac was Abraham's favourite son. Abraham's servant met Rebekah, a beautiful woman, still a virgin, kind and from Abraham's family. According to Derck, it is not an exaggeration to say that Isaac had the perfect wife, according to his father's criteria. However, Rebekah was infertile (Gn 25:21).

This sterility is of course in stark contrast to the hopes of the family, which were conveyed when Rebekah was about to be brought to Abraham's house: 'Our brothers, may you become thousands of thousands, and may your descendants occupy the cities of their enemies' (Gn 24:60). This statement is at the same time a kind of dilemma (it is as if Rebekah is seen as the perfect wife but this is tarnished by the condition she experienced after the marriage; namely she was infertile). This sterility also threatens the continuity of God's promise that Abraham and his descendants will be like the many stars in the sky and the sand in the sea. According to Derck, it is interesting that, unlike the story of Abraham and Sarah, which is depicted as struggling with this situation, Rebekah's sterility is not described in detail by the writer of Genesis. It is also not stated whether Isaac took another wife or approached slaves because of her infertility (Derck 2002:38). The author of Genesis only provides information that Isaac prayed to God and God answered his prayer (Gn 25:21). Rebekah became pregnant and gave birth to twins, Esau and Jacob.

\section{Rachel}

If the situation and problems arising from Rebekah's sterility were not clearly told, something different is found in the story of Rachel. Although she was a wife who was loved by her husband, unlike her sister Leah, Rachel was infertile (Gn 29:31). Conflict in domestic life because of hereditary problems is present in this family. Just as Sarah was jealous of Hagar because she became pregnant and gave birth to Ishmael, Rachel was jealous of Leah, who had four children, Reuben, Simeon, Levi and Judah (Gn 29:32-35).

Like Sarah (Gn 12:11) and Rebekah (Gn 24:16), Rachel is described as a woman with a beautiful appearance (Gn 29:17). However, like Sarah and Rebekah, she had the same problem: childless. To overcome this, Rachel repeated the actions taken by Sara - providing a surrogate mother namely Bilha, her slave girl, who gave birth to Dan and Naphtali. But this moved Leah to do the same. Leah gave her slave Zilpah to Jacob and from her were born Gad and Asher. The rivalry between the two wives continued when Rachel asked for the widower's fruit that Ruben, Leah's son, had. Rachel compensated by allowing Jacob to sleep with Leah. Leah conceived and gave birth to Issachar, Zebulun and Dinah, respectively. After that event, the writer of Genesis says that God remembered Rachel and opened her womb and gave birth to a son. Upon that incident, Rachel said: 'God has taken away my shame'. So he named the boy Joseph, saying, 'May the Lord add another son for me'. (Gn 30:23-24). Several years later, Rachel became pregnant again and gave birth to Benjamin, but she died after the delivery (Gn 35:16-20). That is why, According to Carol Meyers, in the 
context of ancient Israel, the mortality rate for women who gave birth was so high. If the life expectancy of men is around 40 years, then women are lower, which is 30 years. Meyers (1988) referred to Rachel as the representative of the woman who died after giving birth to her second child.

From the Israelites matriarchs' stories, it can be seen that it was not enough for ancient Israelite women to be a wife. They want to be mothers who bear children for their husbands. In the three stories, there is also a similarity that although they were infertile, from their wombs were born important figures in Israel's history, namely Isaac, Jacob and Joseph.

In the context of ancient Israel, children are the hope for the future of the family and nation (Susanta 2019). A child is vital because they are the heirs and the pride and guarantor of Israel's family and country. Therefore, according to Perdue, it is not surprising that reproduction is a vital function of the Israelite family (Gn 1:28; 9:1) and women have a significant role in producing many offspring (Gn 24:60) (Perdue 1997:170). On the other hand, the infertile wife's picture is one of the most potent images of sadness and rejection in the Bible. A wife who cannot have children is often the object of ridicule because of her inability to bear children, especially sons (Gn 30:1-2, 23; 1 Sm 1:6-10) (Ryan 2003:52).

The matriarchs' story is the story of families who struggle with hereditary problems that end in joy, a happy ending. What about Christian families in Indonesia who struggle and are in the same situation as these families? They also expect the presence of children in their marriage. So do not be surprised if the prayer for offspring is one of the prayers that is often heard in the church. In these difficult situations, they might think that God does not care about them even though they try to be loyal to him. Is the Bible text that seems hopeful for a childless family just pseudo entertainment? On the one hand, why did God relieve the suffering of the Israelite matriarchs but, on the other hand, allowing women today to remain in this unfortunate situation? Is not He the same and unchanging God?

\section{The relevance of Christian theological understanding of the handling of infertility in the Indonesian context}

In the Indonesian context, offspring is considered a happiness source for a married couple. Apart from the desire of a married couple to have offspring, the extended family's demands and pressures also determine how much hope there is for a child's presence. It makes couples who do not have children for a long time try hard to have children soon. Various medical and traditional efforts, even those related to religious traditions, will be carried out. These efforts are essential, because the inability to have children, in most families in Indonesia, can create problems in household life. These problems usually manifest in infidelity, divorce or the desire to have more than one wife on the grounds of obtaining offspring. It is not uncommon to understand that infertility is a punishment from God.
Faced with infertility, which is considered a punishment from God, Phyllis Trible, in her book entitled God and the Rhetoric of Sexuality provides an interesting explanation. Trible raised three stories, namely Sara at the palace of Abimelech, Leah and Rachel and Hannah, to show that God is described as the womb's possessor (Trible 1983:34). God protected Sarah by covering the womb of every woman in Abimelech's palace as a form of punishment for taking Abraham's wife - even with Abraham's consent (Gn 20:1-18). In another story, God himself opened Leah's womb as a form of blessing for Leah and God also remembered and opened Rachel's and Hannah's wombs after previously closing the womb (1 Sm 1:1-20). If in Sara and Abimelech's story, God closes the womb as a form of punishment, then there is no explanation why God closed Rachel and Anna's womb, then remembers and opens the womb. Nor does it say that this act was a punishment for these women's sins in the past. It becomes the sovereignty and mystery of God (Trible 1983:35). The story shows that control over women's womb is not with the woman or the husband, but only God has the power to open and close the womb in condemnation, blessing and mystery (Trible 1983:35). Thus, except the story of Abraham and Sarah in Abimelech's court, it can be concluded that infertility is not synonymous with God's punishment. The stories of infertile women in the Bible are lifted to emphasise that God alone is in charge of who can conceive, when and how they can conceive. So it is not related to God's punishment for the husband and wife couple (Susanta 2020).

The sterility of Sarah, Rebekah and Rachel cannot be said to be God's punishment for their sin. The author of Genesis simply shows their infertile condition without an explanation of the cause of the sterility. God promised that Sarah would give birth even though she was infertile. Isaac prayed to God because Rebekah was infertile and God answered her prayer. Whereas in Rachel's case, the writer of the Book of Genesis briefly says that Rachel was remembered by God so that she conceived and gave birth. There was never an explanation for why 'God remembers', nor was it explained why the woman was previously forgotten. From these cases, it is clear that the act of God giving children is to erase their shame and suffering. Once again, this is proof of God's faithfulness to the promises made to their ancestors.

The Old Testament shows that Israel society's system or condition saw that the primary purpose of marriage was to generate offspring. It can be seen from the two existing forms of marriage, for example, polygamy and levirate. Concerning this form of marriage, on the one hand, today's readers should not rush into accusations that it was an arbitrary act on the part of the man against the woman. Possibly, for the context of the era, this was both a common demand at the time (e.g. to provide a large army to survive). However, on the other hand, the form of marriage recorded in the Bible cannot be used as a justification for marriage today. Therefore, divorce and polygamy as reasons for obtaining offspring cannot be justified because they are not following the context of the changing times. When the context changes, people's thinking demands and paradigms should also change. 
Furthermore, the stories of infertile women (matriarchs) in the Bible are not first of all intended to teach that every case of infertility will inevitably end happily (have offspring). Happy endings (i.e. having children) is not the message of these stories, but rather about God's intervention in the life of a family. In short, these stories are raised and told in an attempt to portray God's loyal love and mercy for his people and cannot be viewed as normative or as benchmarks for similar cases occurring today (Susanta 2020).

If having children is understood as a gift from God, does it mean that those who do not have children do not receive God's grace? The answers offered can lead to a misunderstanding of God's grace itself. God's grace cannot only be fixed on one side, for example, a sunny day is a gift from God, whilst a cloudy or rainy day is not a gift from God. God's grace should always exist in various human life situations: health and illness, life and death, success-failure and fertile-infertility.

God's grace in sterility can take or be present in other forms, not in the presence of a child (although God could have carried out that). However, it is no less important to remember that God gives infertile couples gifts. For this reason, the rest of this article will show that infertility experienced by married couples today is not a reproach, a bad thing or a deficiency but a gift of God too. The reinterpretation will lead the congregation and every married couple to interpret infertility not as a problem anymore. Therefore, the next part of this article will offer a Christian theological understanding of the handling of infertility.

\section{Infertility: Opportunity to adopt children}

Children are an inheritance of God, as Psalm 127:3 says. Children belong to God! Through this biblical principle, the congregation is aware that children do not belong to the family exclusively. It means that children's presence in the family is solely a gift from God. Likewise, Elisabeth Kübler-Ross quotes and reaffirms Kahlil Gibran's statement in his book, The Prophet, 'children come through you but not from you, and though they are with you yet they belong not to you' (Kübler-Ross 1983:10).

If we recognise children as gifts that are only obtained because of God's grace alone, then the presence or absence of children in a family should not be viewed as a huge problem. When the children are not yet present in a family, maybe it is because God has not pleased to give his gift of offspring so that humans can only try, but cannot force it.

If the congregation has awareness in this matter, then the church's next step is to offer an alternative solution or step for parents who do not have children but have a desire to care for and raise their children. Congregations can be invited to pay attention to others' lives by adopting children because many children in this world do not have parents. However, it needs awareness that adopted children are not lower in value than biological children. This is important because, from a theological point of view, the strong desire of a couple to become biological parents has indirectly ignored the recognition that all believers are brothers and sisters in Christ, responsible for one another, and that such relationships are not subordinate to biological family relationships (Post 1997:149). This theological principle opens the possibility of understanding that adoption is not merely a second option, but is a response taken by Christians to care for God's children. It does not mean to look at the issue of adoption merely because adoption itself has ethical implications (Post 1997:149). Therefore, the church can also explain that adopting children is not an alternative way of obtaining biological children.

Infertility can be used as an opportunity to adopt - a gift for both the child who will be adopted and the parents who are willing to adopt. However, adoption should not be interpreted as a solution for those who do not have children. If so, there will be a degradation in adoption value: adoption is an escape. Adoption is a husband and wife's commitment before God to become parents. By adopting a child, the husband and wife consciously take on responsibility as parents and carry out the mandate from God.

Adopting a child should be carried out with the child's needs in mind so that a married couple must make some role adjustments in life, which ensures the child's need for love, closeness and acceptance. It is not something easy and requires a healthy mutual commitment. When a husband and wife realise that adoption is an opportunity that God has given, of course, whatever the condition of the child, (different skin colour, gossip from the neighbours or the child's behaviour that is not as expected), will be overcome as a manifestation of Christ's unconditional love.

\section{Infertility: Suffering that deepens a relationship with God}

If a husband and wife decide not to adopt a child, does that mean they do not have the opportunity to get out of these stressful situations and conditions? It can be criticised and reviewed. This understanding is important because if infertility is still understood negatively, then infertility in the family today will always be seen as an unfortunate condition for married couples. A person who is in crisis will fall into despair. The understanding that can be developed is the opposite of despair, namely, hope. The hope that sterility is a gift from God. God's grace should not be taken narrowly only when a child is given. The problem is, how can a married couple interpret infertility as part of God's grace? Is not sterility a source of suffering for humans?

For ancient Israel and modern society today, infertility is synonymous with misfortune and suffering. However, speaking of suffering, Job's book gives rich meaning to suffering. Although in a different context, Job's suffering can be read in the light of the suffering of an infertile couple. Two reasons can be put forward. Firstly, the suffering experienced by infertile couples is often misunderstood because of sin or 
God's punishment. Likewise, his friends considered God's punishment for his sins with Job's suffering. Secondly, in the stories of female infertility in the Bible, it is stated that God is behind the situation, which is indicated by the phrase 'God opens and closes the womb'. Meanwhile, in Job's story, it is also stated God himself was behind Job's suffering, even though this was not God's punishment. For this reason, Job's story will be traced briefly to understand the richness of meaning behind suffering.

In Job's story, before his suffering, he accepted God as the source of goodness. However, after various adversities that had befallen him, the God he believed in now did not seem to be the God he had previously understood. Job was forced to wrestle with a new God (Purnomo 2014:63). In suffering, he came face to face with a completely new God, the mysterious God. Mysterious because God's will is unpredictable. It is the other side of Job's suffering. He is obliged to change his view of God, which he inherited for years, and it is not easy (Purnomo 2014:63-64).

Suffering became part of God's gift to Job's life. The story of Job wants to show a new perspective on understanding suffering. Even though knowing why there is suffering is important, it is not what is essential. The essential thing is to meet God in that suffering. In Job's story, after wrestling with suffering, Job was invited by God to enter into a warm and personal encounter with himself (Purnomo 2014:66). In this encounter with God, Job gained a new awareness of God. He acknowledged his mistake, so far, he saw God humanly (Pidyarto 2014:53). Through Job's story, readers are invited to ponder and understand that the suffering that occurs can be faced with faith in God, who is full of grace, even when humans have no logical or rational reasons to believe.

The suffering of the righteous is sometimes hard to find a reason. However, what is clear is that suffering will deepen the relationship between humans and God. Humans are aware that the most important thing in life is the presence of God, not others, as said Theresia Avilla, 'Solo Dios, Basta' [only God, is enough] (Purnomo 2014:66). Thus, humans are at the same time reminded to be careful in creating the perception that a person's suffering is because of his sins. Through Job's story, humans are invited to believe by faith that God's presence and encounter with him are the greatest gifts in human life.

Situations or conditions that humans perceive as despair and suffering should not be avoided and lamented, but to be faced. Even what is generally viewed as suffering may be a hidden gift of God, which is still elusive for human reason. God's actions on human life cannot be predicted and cannot be regulated according to the will and desire of the human heart.

\section{Infertility: Life glorifying and serving God}

Furthermore, when talking about infertility or the absence of children experienced by a married couple, it is necessary to pay attention to the woman's experience and understanding about infertility she faces. Related to that, Oduyoye (1999), an African feminist theologian, gave an exciting presentation to enrich the discussion around this issue.

According to Oduyoye, in the context of West Africa, if an infertile Christian family who has read the story of the matriarchs asks the question, 'Then why don't I have children?' The church often answers 'Don't say no. But not yet'. Unfortunately, the answer 'no' is not at all helpful and even offers false and empty hopes. Because the Bible is silent on the topic of permanent sterility (Oduyoye 1999:115), that is why Oduyoye often asks herself why the church justifies celibacy (thereby relating the desire to have children) but does not develop a theology that helps and strengthens childless couples (Oduyoye 1999:115). Not infrequently in church wedding ceremonies, the text of Psalm 128 is often raised in sermons (Lembaga Alkitab Indonesia entitled the passage 'Blessings on Households'). The reading of these texts often leaves infertile women today with feelings of guilt (Oduyoye 1999:116). Oduyoye explains that in the context of West Africa, 'there are no empowering words or ceremonies. In this church it is best to be silent, and public reproach is reflected in the sermons from the pulpit' (Oduyoye 1999:116).

Oduyoye's call is a real challenge for the church to make its ministry relevant to people's lives. Although women's struggles in the Indonesian context are not precisely the same as those in West Africa, the crux of the problem is the same: women must become mothers. Therefore, Oduyoye's offer can also be considered for the Indonesian context.

As a feminist who struggles to help release women's shame and guilt, Oduyoye invites women to see procreation differently. Infertile women are invited to come together to understand that their life is praise (doxology) for God and a creative command for them (paraphrasing Gn 1:28):

[I]ncrease in humanity. Multiply the likeness to God for which you have the potential. Multiply the fullness of humanity that is found in Christ. Fill the earth with the glory of God. Increase in creativity. Bring into being that which God can look upon and pronounce 'good', even 'very good'. (Oduyoye 1999:118)

For Oduyoye, infertility in the context of West Africa is a challenge for her womanhood, her humanity and her faith. Because she believes that she lives because of grace, it is the task of the church to generate an understanding of the various gifts of God and at the same time celebrate them (Oduyoye 1999:119).

Then what about married couples who live today? There is always a reason for God's actions. However, there is still not a satisfying and definite answer to God's action. In the OT this nuance is also presented in infertile couple's stories. In the case of the sterility experienced by the people in Abimelech's court, this was understood as God's punishment because Abimelech took Sarah away (even though with Abraham's consent). However, in Sarah, Rachel and Hannah, the Bible does not mention the cause behind their infertility. It is part of God's sovereignty and mystery. Likewise, with 
God's grace. Sometimes this gift remains a mystery to humans. Humans are often unaware of how God's grace works in their lives. Therefore, humans must learn to be sensitive to realise, feel and be grateful for this gift.

As Ashmon and Weise said, God may intend them to use their time and freedom to serve or work to the fullest for those who are ultimately not gifted with children. Those who have children may not be able to do so (Ashmon \& Weise 1998:344-345). However, many people already have children but ignore this responsibility aspect. If a husband and wife do not dare to take on this responsibility, it is better to postpone having children. Children belong to God, that is, husband and wife obtain the mandate and grace when the children are entrusted to them. A husband and wife should not play with this gift because they are responsible to God. Therefore, a childless couple can think about not having children's advantages and disadvantages. Also, even a childless spouse can escape feeling ashamed or guilty because of the situation. That way, they can go through the childless condition with a different zeal. Couples who do not have children can freely enjoy their time and do anything without thinking about the child's condition. There is no limit for them to develop themselves, plan anything freely, help others more freely and have more time and energy and freedom to work and serve God in various fields according to their talents.

\section{Conclusion}

The presence of a child is the dream of almost every family. The absence of children is seen as a disappointment and a cause of suffering for married couples. This applies to ancient Israelite families and to families in Indonesia. This article offers a contribution to the theological thinking that sterility is part of God's grace. This article shows that God's grace can work in various situations in human life. God's grace works when humans are unaware of their presence. That is why every infertile married couple is also invited to struggle and learn to find God's will in their faith journey with God. The presence and encounter with God is a manifestation of God's grace for the husband and wife.

\section{Acknowledgements Competing interests}

The author declares that they have no financial or personal relationships that may have inappropriately influenced them in writing this article.

\section{Author's contributions}

Y.K.S. is the sole author of this research article.

\section{Ethical considerations}

This article followed all ethical standards for research without direct contact with human or animal subjects.

\section{Funding information}

The research received no specific grant from any funding agency in the public, commercial or not-for-profit sectors.

\section{Data availability}

Data sharing is not applicable to this article as no new data were created or analysed in this study.

\section{Disclaimer}

The views and opinions expressed in this article are those of the author and do not necessarily reflect the official policy or position of any affiliated agency of the author.

\section{References}

Albertz, R. \& Schmitt, R., 2012, Family and household religion in Ancient Israel and the Levant, Eisenbrauns, Winona Lake, IN.

Ashmon, S. \& Weise, R.W., 1988, 'Give me children, or I will die: Procreation is God's work', Concordia Journal 24(4), 337-345.

Astiti, T.I.P., 1999, 'Nilai Anak Dalam Kehidupan Keluarga Orang Bali', in Bunga Rampai Sosiologi Keluarga, pp. 226-238, Yayasan Obor Indonesia, Jakarta.

Derck, S., 2002, Barrenness in the Old Testament: Recovering the metaphor, Nazarene Theological Seminary, Kansas City, MO.

Ihromi, T.O., 1981, Adat Perkawinan Toraja Sa'dan Dan Tempatnya Dalam Hukum Positif, Yayasan Obor Indonesia dan Gadjah Mada University Press, Jakarta dan Yogyakarta.

Kübler-Ross, E., 1983, On children and death: How children and their parents can and do cope with death, Touchstone, New York, NY.

Meyers, C.L., 1988, Discovering eve: Ancient Israelite women in context, Oxford University Press, New York, NY.

Oduyoye, M.A., 1999, 'A coming home to myself: The childless woman in the West African Space', in M.A. Farley \& S. Jones (eds.), Liberating eschatology, pp. 163-222, Westminster John Knox Press, Louisville, KY.

Perdue, L.G., 1997, 'The Israelite and Early Jewish family: Summary and conclusions', in D.S. Browning \& I.S. Evison (eds.), Families in Ancient Israel, pp. 163-220, Westminster John Knox Press, Louisville, KY.

Pidyarto, H., 2014, 'Mengapa Orang Benar Menderita?', Wacana Biblika 14(2), 51-57.

Post, S.G., 1997, 'Adoption theologically considered', Journal of Religious Ethics 25(1), 149-168.

Purnomo, A., 2014, 'Penderitaan: Sebuah Anugerah', Wacana Biblika 14(2), 58-64.

Ryan, M.A., 2003, Ethics and economics of assisted reproduction, Georgetown University Press, Washington, DC.

Sanjaya, V.I., 2014, 'Nasib Perempuan-Perempuan Mandul Dalam Alkitab', Wacana Biblika 14(1), 19-27.

Susanta, Y.K., 2017, 'Barrenness: Jalan Penggenapan Janji Allah Bagi Keluarga Allah', Jurnal Jaffray 15(2), 249-262. https://doi.org/10.25278/jj71.v15i2.253

Susanta, Y.K., 2019, 'Tradisi Pendidikan Iman Anak Dalam Perjanjian Lama', BIA': Jurna Teologi Dan Pendidikan Kristen Kontekstual 2(2), 139-150. https://doi. org/10.34307/b.v2i2.127

Susanta, Y.K., 2020, 'Teologi Biblika Kontekstual Di Seputar Persoalan Perempuan, Keturunan, Dan Kemandulan', Religious: Jurnal Studi Agama-Agama Dan Lintas Budaya 4(3), 177-190. https://doi.org/10.15575/rjsalb.v4i3.8079

Trible, P., 1983, God and the rhetoric of sexuality, in W. Brueggemann \& J.R. Donahue (eds.), Fortress Press, Philadelphia, PA. 